\title{
PEMBERDAYAAN MASYARAKAT MISKIN PINGGIRAN HUTAN: STRATEGI MENINGKATKAN PENGHASILAN MELALUI BERKEBUN DAN PEMBUATAN SIRUP JERUK KALAMANSI
}

\author{
Muria Herlina \\ Jurusan Kesejahteraan Sosial FISIP Universitas Bengkulu \\ Email: $\underline{\text { mherlina@unib.ac.id }}$
}

\begin{abstract}
ABSTRAK
Pengabdian ini bertujuan untuk meningkatkan pendapatan masyarakat miskin di pinggiran hutan di Desa Kota Niur Bengkulu Tengah, melalui kegiatan pemberdayaan masyarakat berkebun jeruk Kalamansi (Citrofortunella microcarpa), sebanyak 2200 batang, ditanam pada hamparan tanah seluas 3,5 hektar. Metode yang digunakan dalam kegiatan ini yaitu penggabungan metode participatory mapping (pemetaan partisipatoris), "Diagram Venn Hubungan antar Time line History (alur sejarah masalah dan perubahan di masyarakat), dengan alasan supayah lebih konprehensip dalam pemberdayaan masyarakat, khususnya masyarakat miskin di pedesaan. Hasil pengabdian ini menunjukan setiap bulan anggota kelompok. memperoleh penambahan penghasilan sebesar Rp.400.000 hingga Rp.600.000,-/perbulan. Penghasilan tersebut diperoleh melalui hasil panen masing-masing anggota menghasilakan setiap batang jeruk 2-3 kg/batang (setiap anggota menanam 40 batang jeruk kalamansi, dengan demikian penghasil jeruk antara 80-120 kg dengan harga R.5000,-/kg). Penghasilan lainnya dari hasil pengolahan jeruk pasca panen yaitu membuat sirup dan minuman segar jeruk kalamansi dengan karga minuman kemasan $250 \mathrm{ml}$ seharga Rp.4000,-/botol dan sirup kalamansi untuk kemasan $600 \mathrm{ml}$ seharga Rp.17.500,-/botol. Penghasiln kelompok dari pembuatan sirup dan minuman segar setiap minggu sebesar Rp275.000,- per-minggu/orang. Kesimpulan dengan adanya penambahan penghasilan tersebut, dapat menambah biaya anak sekolah mulai dari PAUD, SD dan SLTP, bisa mengikuti “julo-julo” (arisan) setiap minggu Rp.50.000 dengan anggota 25 orang, Selain itu bisa menabung untuk biaya kesehatan diantara iuran BPJS.
\end{abstract}

Kata kunci: Miskin, pinggiran, hutan, jeruk, kalamansi

\section{PENDAHULUAN}

Desa Kota Niur terletak di kawasan pinggiran hutan Buruh Bukit Kabu, termasuk salah satu desa di Kecamatan Taba Penanjung. Namun sejak 8 Mei 2018 telah disyah pemekaran, maka desa Kota Niur termasuk salah satu desa di Kecamatan Semidang Lagan Kabupaten Bengkulu Tengah, Provinsi Bengkulu, terletak di bagian barat pulau Sumatera (Bapeda Benteng ,2018)

Undang-undang RI nomor 41 tahun 1999 tentang Hutan, Pasa 123 menyatakan pemanfaatan hutan sebagaimana dimaksud dalam Pasal 21 huruf $b$, bertujuan untuk memperoleh manfaat yang optimal bagi kesejahteraan seluruh masyarakat secara berkeadilan dengan tetap menjaga kelestariannya.
Pada kenyataannya bias urban dalam pembangunan menyebabkan ketimpangan antara kota dan desa. Bahkan telah terjadi peminggiran atau marginalisasi di desa, seperti yang dikutif oleh Michael Lipton, dalam (suharjito, 2015). Lebih lanjut dijelaskan semarak pembangunan terjadi di kota-kota besar. kota kecil atau kota kecamatan juga mengalami perubahan-perubahan dengan berbagai aktivitas pembangunannya. Namun, desa-desa yang jauh dari kota, apalagi desa-desa pinggiran hutan (desa hutan), masih sedikit tersentuh oleh program pembangunan.

BPS (2014) melaporkan bahwa jumlah rumah tangga pertanian yang tergolong miskin multi dimensi adalah $21 \%$, rumah tangga pinggiran hutan, sumber utama pendapatan dari subsector 
kehutanan mengalami kemiskinan multi dimensi sebesar $35,7 \%$ paling besar dibanding sub sektor lainnya (Kusumaningtyas, 2013). Jumlah penduduk miskin di pinggiran hutan hampir 12 juta jiwa, mencapai 66,34\% dari penduduk miskin . Jumlah penduduk miskin pinggiran hutan diperkirakan masih banyak (Kharisma,2015)

Penomena di atas mengindikasikan bahawa masyarakat pinggiran hutan memerlukan kepedulian pemerintah untuk meningkatkan kesejahteraan mereka, terutama strategi untuk menambah penghasilan keluarga miskin di pinggiran hutan. Pada kegiatan pengabdian ini salah satu faktor untuk meningkat penghasilan keluarga miskin tersebut melalui pemberdayaan keluarga yang bermukim di pinggiran hutan, yaitu membantu masyarakat memperoleh daya/kekuatan untuk mengambil keputusan dan menentukan tindakan yang akan dilakukan yang terkait dengan pengembangan diri, dalam bentuk berkebun jeruk kalamansi (Citrofortunella microcarpa).

Jeruk Kamanasi dijadikan prioritas dalam pemberdayaan masyarakat, mengingat lokasi keluarga sasaran pengabdian berada di pinggiran hutan, maka tanaman jeruk tersebut dijadikan alternatif yang tepat karena merupakan jenis tanaman yang tidak disukai oleh hama babi, karena buahnya sangat asam. Selain itu jeruk kamanasi merupakan salah satu produk unggulan daerah yang dapat dikembangkan (produk pasca panen) manjadi minuman segar dan sirup kalamansi.

Berkebun jaruk kalamansi mempunyai prospek yang cukup tinggi, karena saat ini sirup kalamansi sudah menjadi icon oleh-oleh dari Bengkulu (Caturini, 2014), pengunjung atau wisatawan domostik merasa tidak lengkapa jika tidak membawa oleh-oleh dari Bengkulu seperti sirup kalamansi yang mempunyai aroma yang harum (khas harum jeruk kalamansi)

\section{METODE}

Metode penggabungan participatory mapping (pemetaan partisipatoris), metode "Diagram Venn Hubungan antar Lembaga dan Time line History (alur sejarah masalah dan perubahan di masyarakat (Adi, 2007). Meliputi kegiatan sebagai berikut (1) mengidentifikasikan area lingkungan masyarakat sasaran masalah terutama masalah yang sangat mengganggu masyarakat dalam hal kesulitan untuk menambaha penghasilan, mengamati potensi-potensi yang terkait dengan aset-aset komonitas.Tujuan menggunakan metode ini tim perencana partisipatoris dapat membantu menjelaskan perubahan-perubahan yang terjadidi masyarakat. Hal ini biasanya akan muncul ketika masyarakat mencoba menjelaskan peta yang mereka buat. Tahapan kegiatan adalah sebagai berikut:

\section{Penetapan anggota dan kelompoks} asaran:

Membentuk kelompok sasaran yaitu masing-masing anggota kelompok terdiri dari 7 orang dan disepakati ada 7 kelompok, dengan demikian anggota sasaran 49 KK dan 1 anggota lainnya yaitu kepala desa. Jumlah keseluruhannya adalah 50 anggota sasaran.

\section{Pentetapan Lokasi}

Desa Kota Niur tergolong desa yang terisolir berbatasan langsung dengan penambangan batu baru Pin Shi Ang perusahaan China-Korea.Terletak di pinggiran hutan buruh bukit kabu, yang dikenal olah masyarakat dengan sebutan "Bukit Kucing" karena di dalam hutan tersebut masih ada harimau, kata kiasan kucing artinya harimau. Jalan menuju lokasi kegiatan yaitu di Desa Kota Niur melalui yang biasa digunakan mabil truk pengangkut batu bara, dengan kondisi jalan berkoral, berdebu dan banyak tanjakan. Di ujung desa ada hamparan lebih kurang 5 ha, dahulunya hutan merupakan tanah terlantar/lahan tidur, lahan tersebut ditetapkan/dijadikan sebagai lahan tempat pembinaan kegiatan pengabdian.

\section{Pentetapan Jenis Tanaman:}

Mengingat lokasi lahan pembinaan yang berada di pinggiran hutan, dengan kondisi masih banyak hama babi, maka ditetapkan komoditas 
utama adalah jeruk kalamansi (Citrofortunella microcarpa). Dengan alasan tanaman jeruk tersebut tidak dimakan/ diserang hama babi, karena buah jeruk kalamansi rasanya sangat asam. Keasaman buah tersebut membuat hama babi tidak mau memakannya, artinya aman dari serangan hama babi.

4. Pengadaan bibit jeruk kalamansi:

Masing-masing anggota kelompok mendapatkan 40 batang jeruk kalamansi untuk jumlah seluruh 50 anggota, dengan demikian jumlah pengadaan bibit sebanyak 2000 batang jeruk kalamansi ditambah lagi disediakan untuk penyulaman tanaman 200 batang, sehingga jumlah keseluruhan 2200 batang yang ditanam pada hamparan tanah seluas 3,5 hektar.

5. Pendampingan penanaman jeruk kalamansi

6. Pendampingan pemasaran dan produk pasca panen, berupa sirup dan minuman segar Kalamansi

7. Evaluasi dan pelaporan

\section{HASIL dan PEMBAHASAN}

\section{A. Pendampingan Pengolahan Lahan} Letak lokasi dan kondisi pengabdian sangat sulit dikerjakan secara manual, karena berada di pinggiran hutan dengan kemiringan 40 derajat hingga 65 derajat, maka lahan dikerjakan menggunakan mesin alat berat yaitu traktor dan excavator.

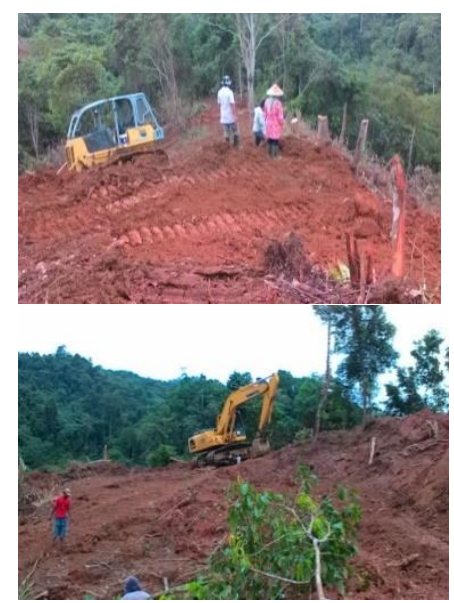

Pengolahan Lahan Perkebunan Jeruk Kalamansi

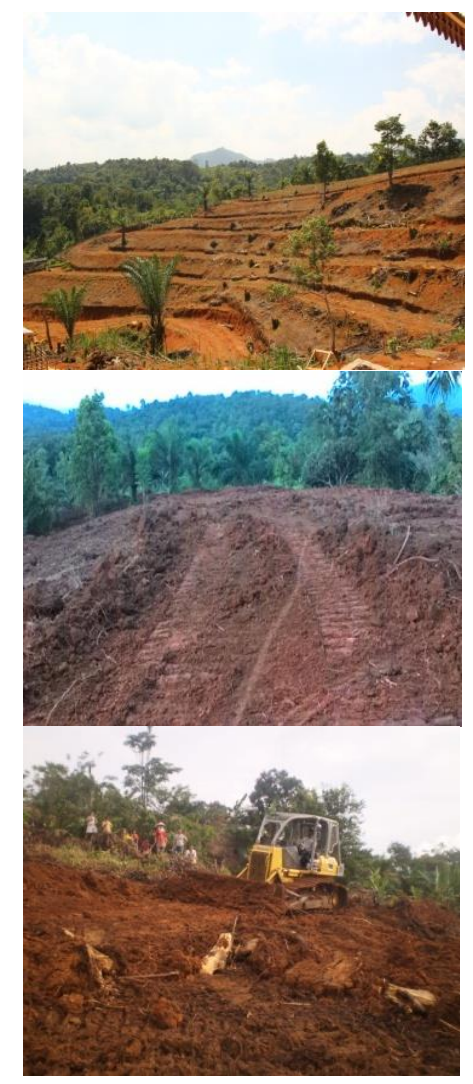

Hamparan Lahan 3,5 herktar siap di tanama jeruk Kalamansi

\section{B. Pengadaan dan Penanaman jeruk} Kalamansi

Setelah pengolahan lahan, selanjutnya dilakukan kegiatan pengabdian berikutnya yaitu mempersiapkan pengadaan bibit jeruk kalamasi. Pengadaan bibit jeruk kalamansi dipilih dari sambung pucuk. Bibit tanaman hasil sambung pucuk mempunyai keuntungan yaitu bersifat identik dengan sifat genetik tanaman induk, mempunyai perakaran sangat baik yang diperoleh dari sistem perakaran batang bawah, mempunyai tingkat keseragaman penampakan tanaman yang sangat baik saat ditanam di lahan, tingkat pertumbuhan yang relatif seragam yang mana pada kondisi lingkungan yang mendukung akan tumbuh lebih cepat (Siswanto, 2017) 


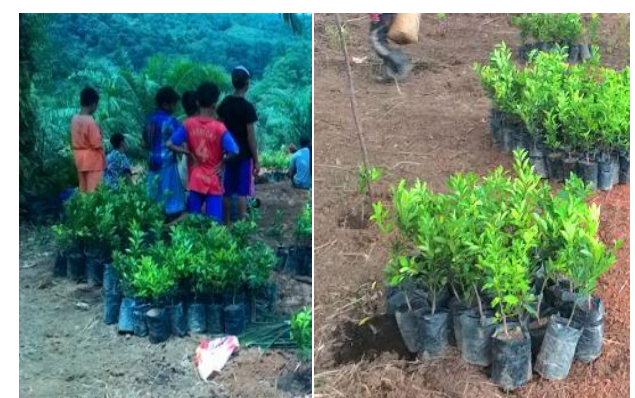

Pengadaan bibit dan proses penanam jeruk kalamansi

Jarak tanam 3 meter, teknik tanam mata lima

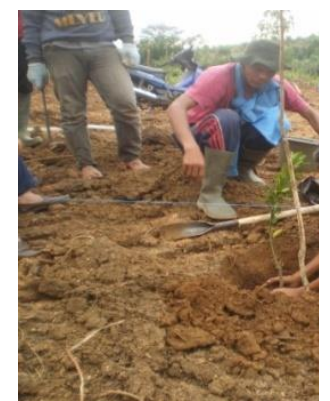

Gambar A

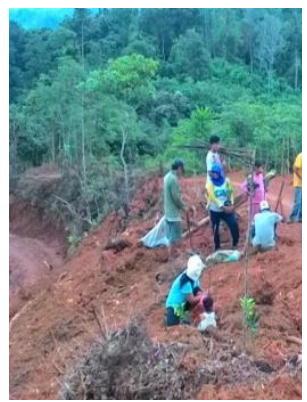

Gambar B
Sistem penanaman jeruk kalamansi pertama diahului dengan pengajiran jarak tanam masing-masing 3 meter, menggunakan teknik mata lima, selanjutnya kedua dilakukan pembuatan lobang tanam 25x $25 \mathrm{~cm}$ dan kedalaman $25 \mathrm{~cm}$, tepat pada di tengah ajir. Tahap ketiga adalah pemberian pupuk kompos yang sudah jadi, sebanyak tiga perempat lubangtanaman (gambarA). Keempat, tahap akhir langsung penanaman bibit jeruk kalamnsi (gambar B). Ajir tetap terpasang untuk penahan bibit jeruk tidak jatuh kena tiupan angin.

\section{Perkebunan Jeruk Kalamansi}

Sama dengan perkebunan jeruk pada umumnya, untuk menghasilkan kebun jeruk yang subur setelah penanam dibutuhkan perawatan seperti penyiraman, pemupukan, penimbunan, penyulaman, pengendalian gulma dan hama. Berikut foto kebun jeruk kalamasi. Daya tumbuh bibit jeruk kalamansi yang berasal dari sambung pucuk mencapai $97 \%$, sehingga penyulaman tidak banyak dilakukan, karena tingkat kematian bibit hanya 3 persen.

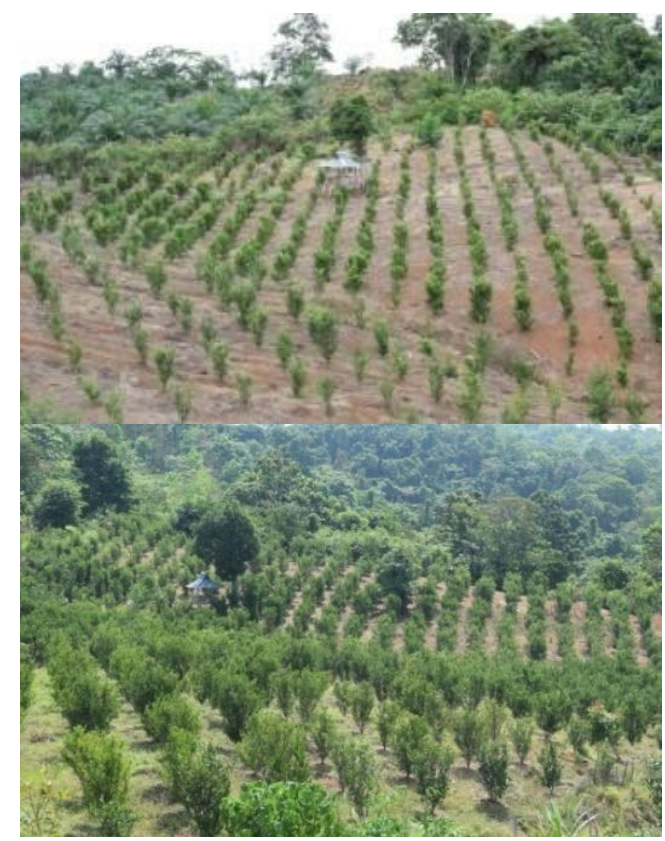

Kebun Jeruk Kalamansi umur 6 bulan

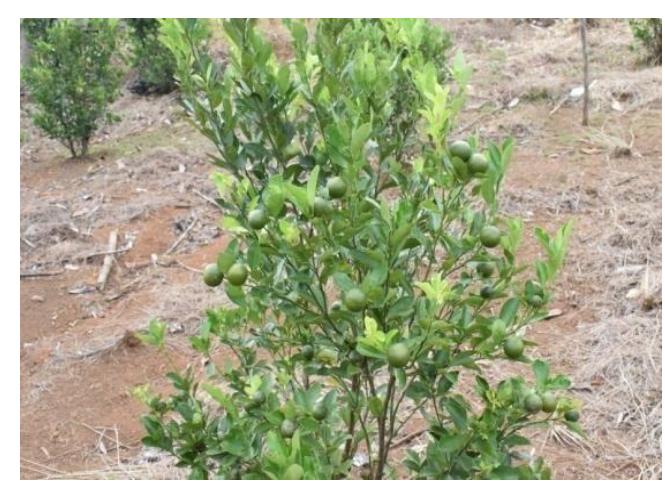

Pohon jeruk kalamansi umur 19 bulan sedang berbuah

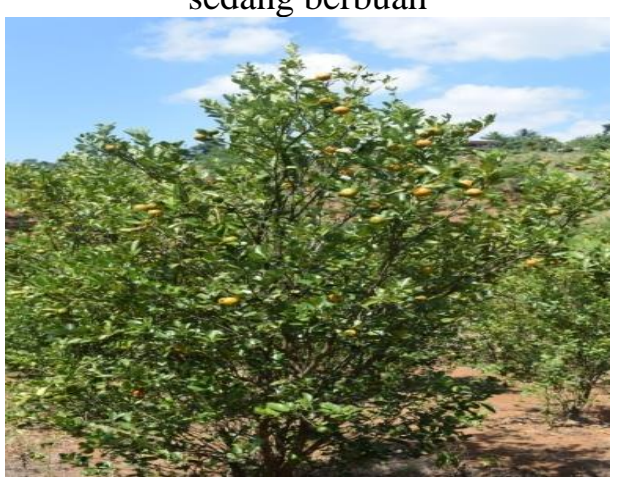

Buah jeruk kalamansi siap panen Umur 24

\section{Hasil Panen Jeruk Kalamansi}

Jeruk kalamansi memiliki dua jenis yaitu yang berbuah warna kuning dan ada yang berbuah kuning kehijauan apabila siap panen. Buahnya kecil dan mempunyai aroma harum yang khas serta rasanya asam. Petani pada umumnya banyak menjual secara 
langsung berupa buah jeruk kepada pengerajin sirup kalamansi, tukang sate, mie pangsit, penjual minuman dan lainnya. Saat ini jeruk kalamansi banyak diminati di dalam maupun luar Provinsi Bengkulu, karena selain menjadi tanaman unggulan daerah (Provinsi Bengkulu), banyak permintaan konsumen dari luar Bengkulu dalam bentuk sirup kalamansi. Berikut hasil panen buah jeruk kamanasi.

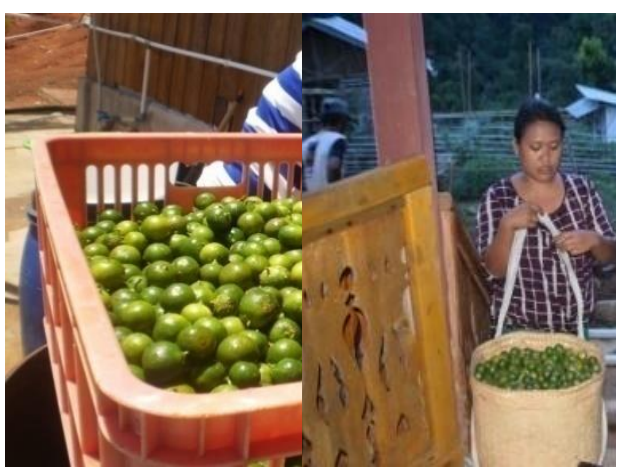

Hasil panen buah jeruk kalamnsi

Sebagaiman sudah dijelaskan di atas, pada umumnya petani jeruk kalamansi menjual langsung dalam bentuk buah jeruk. Setiap batang menghasilkan buah sebanyak 2-3kg. Masing-masing anggota mempunyai 40 batang, artinya setiap anggota dapat menghasilkan panen jeruk sebanyak minimal $80 \mathrm{~kg}$ hingga $120 \mathrm{~kg}$ setiap bulan. Harga buah jeruk kalamansi Rp.5000,- $/ \mathrm{kg}$. Jika ditotalkan penghasilan anggota perbulan minimal Rp.400.000,- hingga Rp. $600.000,-/$ bulan.

\section{E. Pendampingan Pengolahan Pasca Panen}

Pengolahan pasca panen buah Jeruk kalamansi selain dijual secara langsung berupa buah mentah, dapat pula dari sari buah jeruk kalamasi lalu dibuat sirup dan minuman segar kalamansi, dengan rasa yang segar asam-asam manis. Minuman kalamansi akan lebih segar/nikmat jika disajikan dalam keadaan dingin. Dua sendok makan sirup kalamansi diseduh dalam segelas air matang sudah menjadi minuman segar kalamansi, berikut proses pembuatan

sirup kalamansi secara manual (tradisional) tidak menggunakan peralatan mesin :
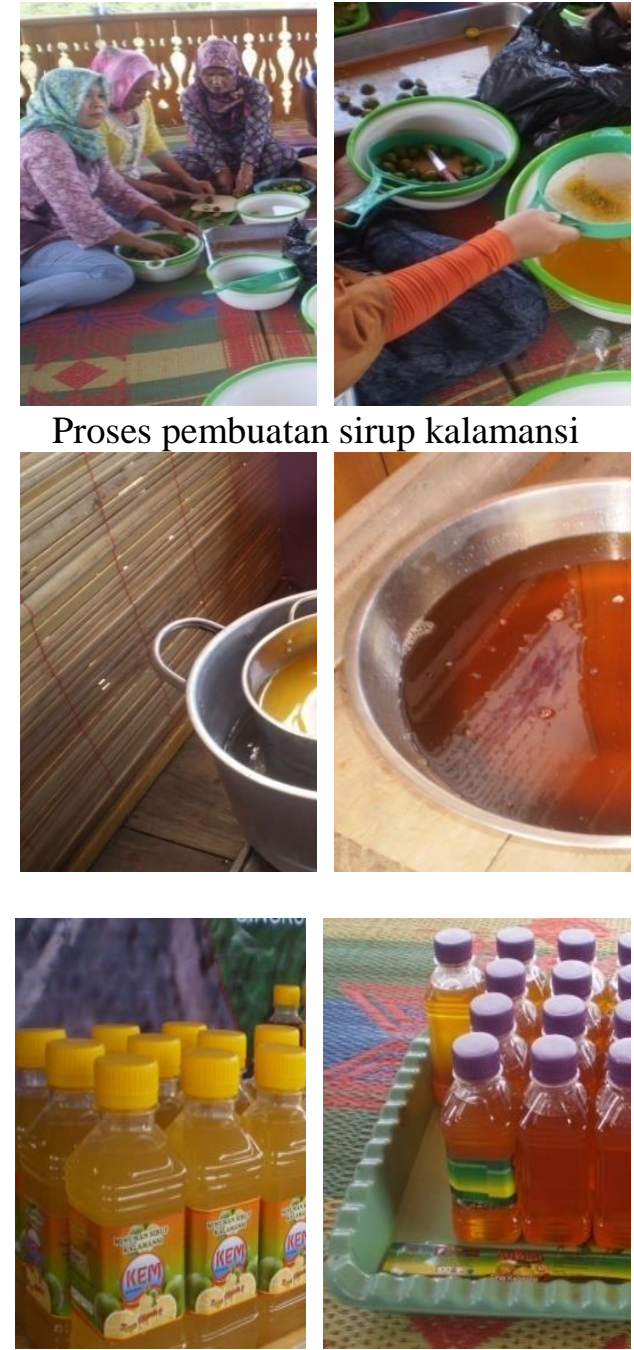

Sirup dan Minuman kalamansi siap dipasarkan

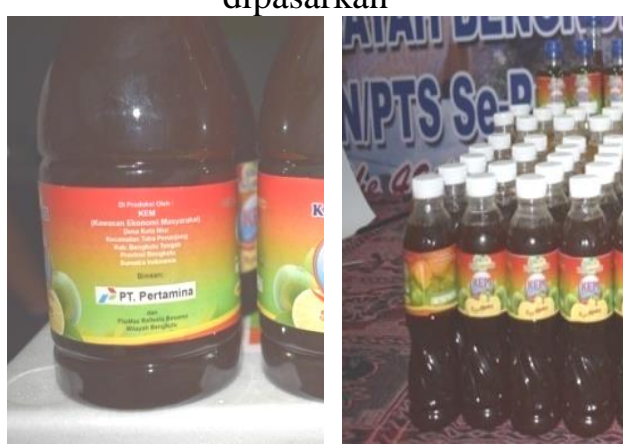

Dari dua jenis kegiatan produk pasca panen tersebut yang paling menjanjikan untuk peningkatan pendapatan yaitu melalui penjualan minuman segar kalamansi. Disamping harganya tinggi dan dapat disimpan selama 3 bulan dalam plizeer box.Sirup kalamansi kaya vitamin $\mathrm{C}$ dan dapat menurunkan 
berat badan (surlita at.al, 2017). Harga Sirup kalamnsi dalam kemasan $600 \mathrm{ml}$ adalah Rp.17.500,-/botol, sedangkan minuman segar kalamansi kemasan $250 \mathrm{ml}$ seharga Rp4000,- hingga Rp.5000,-/botol.

\section{KESIMPULAN}

Kegiatan

pemberdayaan masyarakat pinggiran hutan melalui kegiatan pengabdian budidaya jeruk kalamansi mempunyai nilai prospek yang tinggi, karena sirup dan minuman kalamansi berbahan baku jeruk kalamasi yang memiliki aroma harum khas jeruk kalamansi dan dinikmati/dimanfaatkan oleh wisatawan domestik sebagai bahan oleh-oleh dari Bengkulu. Hasil kegiatan menunjukan adanya peningkatan penghasilan anggota sasaran, yaitu sebesar Rp.450.000,- singga Rp.700.000/bulan, sehingga dapat dimanfaatkan untuk kebutuhan keluarga seperti keperluan rumah tangga, pendidikan anak dan menabung melalui julo-jolo (arisan).

\section{UCAPAN TERIMA KASIH}

Ucapan terimakasi disampaikan kepada PT.Pertamina (Persero) Jakarta, telah memberikan kepercayaan mengolah dana bina lingkungan, untuk pemberdayaan masyarakat miskin pinggiran hutan Desa Kota Niur Kecamatan Semidang Lagan BengkuluTengah. Dan terima kasih juga kami sampaikan atas bimbinaan dan pengarahan dari ketua dan tim FpliMas Indonesia, hingga berhasinya kegiatan pemberdayaan ini.

\section{DAFTAR PUSTAKA}

Adi Rukminto Isbandi, 2007.

Pemberdayaan, pengembangan

masyarakat dan intervensi

komunitas, Fakultas Ekonomi UI.

Jakarta

Caturini Rizki, 2014. Hasil berlipat dari budidaya jeruk kalamansi, https://peluangusaha.kontan.co.id/ne ws/hasil-berlipat-dari-budidayajeruk-kalamansi. diakses 21 Oktober 2017.

Kharisma Wilujeng, 2015. 12 Juta Masyarakat Pinggiran HutanHidup Miskin, $\quad$ http://www.pikiran- rakyat.com/nasional/2015/06/12/33

0796/12-juta-masyarakat-

pinggiran-hutan-hidup-miskin, 12 Juni 2015 (05:09.

Kusumaningtyas Rahajeng dan Chofyan Ivan, 2013. Pengelolaan hutan dalam mengatasi alih fungsi lahan hutan di wilayah kabupaten subang, JURNAL Perencanaan Wilayah dan Kota ... Vol 13, No 2 (2013)

Siswanto Dwi, 2017. Panduan teknik perbanyak tanaman buah sambung pucuk,

https://www.dwisangpetani.com/201 7/02/panduan-lengkap-carasambung-pucuk-pada-tanaman.html. diakses 22 Agustus 2018

Suharjito Didik, 2015. Kesejahteraan Masyarakat Pinggiran Hutan, http://www.pikiranrakyat.com/nasional/2015/06/12/330 796/12-juta-masyarakat-pinggiranhutan-hidup-miskin.Diakses 12 Desember 2017

Surlita Sutemu at.Al, 2017. Perbaikan Profil Lipid Pada Perempuan Dewasa Kelebihan Berat Badan Setelah Intervensi Sari Jeruk Kalamansi (Citrus Microcarpa), J. Gizi Pangan, Juli 2017, 12(2):93-10 